\title{
Eco-financing for low-carbon buildings and cities: Value and limits
}

Jeroen van der Heijden

Australian National University

\section{Abstract}

Building owners and governments face constraints in financing the transformation and development of low-carbon buildings and cities. Banks and other finance providers are often risk-averse and unwilling to provide funds for such development and transformation. For some time now, governments and non-governmental organisations have experimented with novel forms of financing for low-carbon developments and transformations-often referred to as 'eco-financing'. This article studies six such governance instruments from Australia, the Netherlands and the United States to better understand their value and limits.

\section{Key words}

Experimental governance, eco-financing, low-carbon development and transformation, urban environmental governance, scalability

\section{Acknowledgements}

This article was supported by a VENI-grant from the Netherlands Organisation for Scientific Research (NWO; grant number 45111015) and a DECRA-grant from the Australian Research Council (grant number DE15100511). Many thanks to two anonymous reviewers for suggested changes to an earlier version of the article. All usual disclaimers apply. 


\section{Introduction}

Buildings and cities are essential in the global response to climate change. Cities make up less than five per cent of the earth's landmass, but it is in cities that most resources are consumed and waste is produced-including 70 per cent of global energy consumption and 70 per cent of global carbon emissions. At the same time, buildings and cities hold much potential for significant reductions in resource consumption and waste production. Well trialled technology and knowledge of behavioural change is available to achieve reductions of up to 80 per cent at building level (IPCC, 2014; Van der Heijden, 2014b).

To achieve these reductions this technology and knowledge needs appropriate application, on a large scale, and in a timely manner. Governing this transition is complicated, however. To date, traditional governance instruments-such as direct regulatory interventions, subsidies, and taxeshave not been able to incentivise a large uptake of technology and knowledge (Bulkeley, 2002; James, 2015). Another complication is financing. Whilst some building owners and developers are willing to improve the carbon intensity of their existing or future buildings well beyond what is required by mandatory regulation, banks and other finance providers are often found hesitant to provide funds for low-carbon building and city development and transformation. They fear that the environmental sustainability credentials of buildings will not be reflected in their market value, which implies a risk if their owners cannot pay back the loans or mortgages provided (Bals, Warner and Butzengeiger, 2006; World Bank, 2011).

In seeking to overcome this barrier to financing, governments, firms, and civil society organisations have begun to experiment with novel forms of financing for low-carbon building and city development and transformation - these fit a broader trend of 'eco-financing' instruments (discussed in more depth below). These instruments seek to take away the risks experienced by banks and other finance providers, or they seek to directly support sustainable building development and retrofit projects that cannot find financial means elsewhere. Administrators of these novel financing instruments argue that by improving the resource efficiency of buildings (and the related reduced carbon emissions) their owners save money, as they face lower electricity bills than when owning or leasing conventional buildings. These cost savings can then be used to repay the funds provided.

Whilst there have been experiments with such novel forms of financing for some time now, little is known of their performance (Ali and Yano, 2004; Matthews, 2015; Van der Heijden, 2014b). Are they capable of accelerating the transition to low-carbon buildings and cities and how might they achieve this? What are their values, and what are their limits? These questions are central to this article, which seeks answers by closely studying six novel forms of financing-one from 
Australia, two from the Netherlands, and three from the United States. They are studied as part of a larger, multi-year research project on experimental governance instruments for low-carbon city development and transformation. ${ }^{1}$ They were selected because of their mutual goal (reducing the energy and carbon intensity of commercial and residential buildings), but also because of their slightly different approaches to achieving this goal.

The article unfolds as follows. The next section briefly introduces the problem of financing for low-carbon building and city development and transformation, the novel financing instruments that have emerged, and reflects on the governance literature in order to express expectations about performance at building and city level. The section that follows briefly discusses the research methodology and approaches to data collection and analysis, and then a discussion of the six novel financing instruments and their performance. The main findings are summed up in the discussion section, and the final section draws conclusions.

\section{Novel forms of financing: An experimental governance theory perspective and expectations}

The novel forms of financing low-carbon building and city development and transformation studied in this article fit a larger trend of what has become known as 'eco-financing' (Chou, Hammer and Levine, 2014; Matthews, 2012; XiaoHu Wang, Hawkings and Berman, 2014). Eco-financing includes (traditional and innovative) economic governance instruments such as emission trading and taxes, charge systems including user fees and pollution levies, and liability systems including environmental insurance and legal liabilities (Ali and Yano, 2004; Castellucci and Markandya, 2012; Panayotou, 1998). These governance instruments build on a popular win-win narrative: that improved resource efficiency at building and city level (and related reduced carbon emissions) come with financial gains for those participating in these instruments. In other words, so argue the administrators of these novel financing instruments, sustainable buildings require fewer resources to operate, implying fewer costs for their owners and users, making them more capable of paying back loans, mortgages, and other funds provided (Kats, Menkin, Dommu and DeBold, 2012; Kirkpatrick and Bennear, 2014).

Banks and other funds providers do not, however, argue this way. They are concerned that the additional cost that comes with improving resource efficiency and reducing the carbon intensity of existing and future buildings will not be represented in the market value of these buildings. They perceive a risk that lenders will not be able to pay back the additional funds provided (Pivo, 2010; Xiadong Wang, Stern, Limaye, Mostert and Zhang, 2013). The idea that future gains in sustainable buildings-lower operation costs, among others-improve a building owner's ability to pay back

\footnotetext{
${ }^{1}$ For a full overview of the study see http://www.jeroenvanderheijden.net/research current VENI database.html
} 
loans and mortgages does not fit the traditional financing business model that builds on the idea that money invested will result in improved profit. These business models are based on cash flows from production and economic growth (Bals et al., 2006; World Bank, 2011). The global financial crisis (of 2008-2011) has only worsened this situation of risk averse banks and financial institutions (Coiacetto and Bryant, 2014; Venugopal, Srivastava and Polycarp, 2012).

It is not only banks and other financial institutions that are risk averse, property owners are too. They might be concerned that they will not own a property long enough to recoup the upfront costs through reduced operation costs, they might not value the long term gains over the short term costs (hyperbolic discounting), or they may face a situation of split-incentives between their making the investments but their tenants receiving the gains in terms of reduced operation costs (Ameli and Brandt, 2015; Swan and Brown, 2013). The novel forms of financing studied in this article thus give a striking illustration of the different lenses through which various people and organisations look at the opportunities and constraints of addressing the resource efficiency and carbon intensity of buildings and cities: some see and present a financial win-win opportunity that they happily take, others see a financial risk that they would rather not take (cf. Hoffman, 2015).

The novel forms of financing studied in this article also provide illustrative examples of what has become known as 'experimental governance'. Scholars of experimental governance argue that complex societal problems, such as the transition to low-carbon buildings and cities, can no longer be governed through traditional top-down mandatory regulatory interventions, nor through conventional market mechanisms. They argue that local governance solutions are required for local problems, and that these governance solutions have to be developed in collaborative processes involving those who govern and those who are governed (Borzel, 2012; Davis, 2011). Through such collaborative and consensus oriented approaches the tacit knowledge of those governed can be included in the development and implementation of governance instruments, which may further their (local) effectiveness (De Burca, 2010; Sabel and Zeitlin, 2011). Finally, these scholars argue for a wider repertoire of governance instruments than traditional government-led direct regulatory interventions, and argue for combining traditional regulatory approaches (setting standards, monitoring, enforcement) with market-based incentives (rewarding compliance); and they argue for governance instruments that incentivise voluntary rather than mandatory participation (Evans, 2011; Van der Heijden, 2014a). At building and city level, governance experimentation is considered particularly promising because of scaling possibilities: if an experimental governance instrument works in a specific part of a city, then it, or the lessons learnt from it, might easily be scaled up to other parts of the city or even to other cities (Sassen, 2015). 
Whilst experimental forms of governance have received much acclaim in the literature, concerns have also been expressed. Some scholars argue that whilst experiments may achieve promising results in one context it will be difficult to replicate these in other contexts. Small differences among contexts in, for example, legal requirements, may have considerable impact on an experiment's performance. Others warn that the original participants in an experiment have specific incentives to ensure its success. Such motivations may, however, not be shared by the broader population, implying that once an initiative is formalised in public policy it will not yield the same results as during its experimental phase. Finally, whilst experimental governance is not limited to a specific size, studies find that the scale of experiments is often too small to have meaningful impact (Bai, Roberts and Chen, 2010; Bulkeley and Broto, 2013; Van der Heijden, 2014a).

The six novel forms of financing studied in this article all fit the design characteristics of ecofinancing and experimental governance-some meet many, others meet a few. Some of the instruments were initiated by city governments that have set more ambitious carbon emission reductions than their national governments, others were initiated by non-profit organizations. Most were developed in collaboration with the local actors they govern. All instruments focus on reducing office- and residential building-related resource consumption or carbon emissions; all instruments build on voluntary participation; and they all built on a win-win narrative that reduces carbon emissions at building and city level, with financial gains for property owners. They reward participants with funds, but also with knowledge of how to achieve resource consumption or carbon emission reductions. In sum, these six instruments are illustrative of what may be expected to be promising experimental governance instrument designs, as well as promising eco-financing designs.

The six novel forms of financing can be divided into three distinct types: environmental upgrade financing, revolving loan funds, and energy efficiency mortgages-each type is represented by two instruments. Table 1 presents a brief summary of the instruments studied.

\section{TABLE 1 ABOUT HERE}

\section{Research design}

The six novel financing instruments were studied as part of a larger research project on experimental governance for low-carbon building, and city development and transformation globally (Van der Heijden, 2016). Cases (experimental governance instruments) were identified through internet searches and desk research. They can be understood as illustrative of the broader trend of experimental urban governance described above. By no means, however, does this article claim that 
the six examples are representative of all possible designs and contexts of novel forms of financing for low-carbon building and city development and transformation around the globe.

The relevant data for analysing the instruments was obtained from websites, reports, and other sources. New data was obtained through a series of interviews. This was to fill gaps in the data from other sources, to resolve conflicts in data from other sources, and to gain additional insight into the instruments under scrutiny. Interviewees were recruited through internet searches and socialnetwork websites, particularly LinkedIn. Over 200 interviewees from various backgrounds, including policymakers, bureaucrats, property developers, architects, engineers, and property owners, were involved in the larger research project. Of these, 30 were interviewed for insights into the six instruments studied here.

The interviews were recorded and, based on the recording and notes taken during the interviews, a summary report was drafted that was returned to the interviewees for validation. The interviewees were often aware of, and involved in, more than one experimental governance instrument. It is expected that this (partly) helped to overcome the sampling bias of administrators (and participants) who were overly enthusiastic about their 'own' example (Sanderson, 2002). Interviews lasted for approximately one hour and were generally conducted the interviewee's work location. The interview data and additional data were processed by means of a systematic coding scheme and qualitative data analysis software (Atlas.ti). Using this approach, the data was systematically explored and insight was gained into the 'repetitiveness' and 'rarity' of the experiences shared by the interviewees.

Each of the novel financing instruments studied was assessed through the following questions: What is the performance of the instrument? What are the main lessons learnt? What is the potential to scale up the instrument or the lessons resulting from it throughout the city, or even to other cities? These questions follow other studies of experimental urban governance instruments (e.g., E. Boyd and Ghosh, 2013; Hohn and Neuer, 2006).

\section{The six novel forms of financing studied}

In the following, each type of instrument studied is addressed in light of the questions that guided the research. To prevent too much overlap between the instrument descriptions, however, this section specifically focuses on the unique insights that were drawn from each.

\section{Environmental upgrade financing: PACE and 1200 Buildings}

In this type of instruments, governments act as intermediaries in generating funds for environmental upgrades. They seek to take away risks experienced by banks and other finance providers in 
supplying funds for low-carbon building retrofits. In the instruments studied, governments obtained funds-from banks or other providers-and supplied these to property owners. Property owners committed to using these funds to retrofit existing buildings in line with the instrument's rules. This design was first introduced in the United States as a nation-wide program in 2008: Property Assessed Clean Energy (PACE). It was developed and implemented by PACENow, a non-profit organisation.

PACE helps commercial property owners to access long-term loans for energy retrofits and upgrades. ${ }^{2}$ Loans are sought from local governments and PACE provides a framework and guidelines for government and property owners to come to agreement about how the loans are being used. PACE allows local governments and property owners to enter into tailored agreements that take into account the specific circumstances of property owners and their property. Once they have entered into an agreement, the local government issues a bond on behalf of the property owners that can be purchased by a third party finance provider. After obtaining funds, the local government supplies these to the property owner who uses them for energy efficiency retrofits and upgrades following the agreement. The local government recoups these funds - with interest-through an additional property tax on the property, and pays back the funds and interest to the third party finance provider. In order to be allowed to impose this additional property tax, PACE requires that state and local government enact legislation that allows for PACE financing. By 2015, 30 states had such legislation in place, with 13 states actively using it (PACE Now, 2015).

Administrators of local PACE programs in San Francisco and Sacramento believed that one of the main strengths of the program is that it ties the funds provided to the building and not the building owner: because the funds provided are recouped through the additional property tax, the duty to repay the funds provided moves to the new property owner if the building changes ownership. Another main strength, they said, is the involvement of local governments as risk-takers. 'The repayment obligation is secured through the property taxes and that allows us to advertise [the bonds] over a 20 year repayment period at competitive rates', a PACE administrator in San Francisco (int. $179^{3}$ ) told. 'It is a secure new class of asset investment that provides longer term repayment periods. It creates positive cash flows', he continued. An additional strength of the instrument is,

\footnotetext{
2 PACE initially was applied to commercial and residential property, but as a result of the subprime mortgage crisis of 2008 the United States mortgage authorities (Fannie Mae and Freddie Mac) refused to finance mortgages under PACE (Bird \& Hernandez, 2012; Kirkpatrick \& Bennear, 2014; Sichtermann, 2011). Change is in the air again, however, with an announcement by President Obama about revitalising the residential part of PACE (www.pacenation.us 29 December 2015).

${ }^{3}$ Interviewees were promised anonymity in research publications. Interviewees are numbered consistently throughout all publications resulting from the larger project.
} 
they said, that the tax can be transferred to the tenant of a building. This helps to overcome the often-experienced split incentive problem between landlord and tenant (discussed above).

Local governments in Australia have implemented novel financing instruments that build on a comparable design. The 1200 Buildings instrument, implemented in 2010 by the City of Melbourne, is one of these. It differs from PACE slightly, however, in the way the City of Melbourne seeks to obtain funds. Instead of issuing bonds on behalf of property owners, as under the PACE program, the government of Melbourne has entered into agreements with finance providers, and borrows funds directly to supply these to property owners. Funds are paid back by property owners through a newly introduced property tax, which required local legislative change. The instrument sets strict criteria for property owners. It requires that property owners commit to improving the energy efficiency of their buildings by 38 per cent by 2020 (da Silva, 2011). This relates to the city's greater ambitions of reducing resource consumption and carbon emissions - this again differs somewhat from PACE, which allows for more tailored agreements between local governments and property owners, and sets less ambitious overall carbon emission reduction goals. When interviewed in 2011, just after 1200 Buildings in Melbourne was launched, one of the 1200 Buildings' administrators (int. 26) was convinced that the instrument would quickly attract a substantial number of property owners: 'The finance incentive [provided by 1200 Buildings] has created a strong value proposition and that is something that building owners are interested in', she argued.

During the research project it became clear, however, that these instruments struggled considerably to attract property owners. By 2015, fewer than 500 commercial buildings were committed to PACE. Bearing in mind that there are about 5.5 million commercial buildings ${ }^{4}$ in the United States that could participate in PACE, this performance may be considered marginal, at best. Similarly, 1200 Buildings in Melbourne has achieved only marginal uptake. The instrument aimed to see all of Melbourne's 1,200 inner-city commercial buildings retrofitted by 2020, but by 2015, halfway through its lifetime, a mere 50 buildings had been committed to the instrument-of which fewer than ten had been retrofitted. What explains this marginal performance?

The way property owners are targeted, in particular, appears to explain the poor performance of these instruments. The programs market their key benefits for participants mainly in terms of interest only to large corporate property owners: 'Improving corporate image', 'Lower environmental footprint and greenhouse gas emissions', and 'Making the building more attractive to investors', the 1200 Buildings website states ${ }^{5}$-PACE is marketed in similar terms. ${ }^{6}$ Only some 10 per cent of commercial property in Melbourne's central business district (the area targeted by 1200

\footnotetext{
${ }^{4}$ Data from: www.eia.gov (21 July 2015).

55 See: www.pacenation.us (29 December 2015).

${ }^{6}$ See: www.melbourne.vic.gov.au/1200buildings/Pages/GoodForBusiness.aspx (10 August 2015).
} 
Buildings) is owned by large corporate property owners, however, and the vast majority of property is owned by private owners-small and medium sized firms and individual commercial property owners. ${ }^{7}$ The key benefits marketed do not appear to resonate with them. 'Private owners often do not have the corporate structures and resources to research, facilitate and track building performance,' the team leader of 1200 Buildings told (quoted in Aliento, 2014). They are often not aware of the energy performance of the building or buildings they own and take a passive stance on building energy performance. Compared to large firms, they consider building energy retrofits a sunken cost rather than an investment that might generate cash flow in the form of energy cost savings (Perinotto, 2014). They see little justification for long-term investments in their property: 'It's a long lag time', the 1200 building administrator (int. 26) explained in a follow up interview in 2015, 'it's about changing building owners thinking in short term benefits to thinking in long term benefits'. The administrator of PACE in San Francisco (int. 179) shared comparable experiences: 'There is a demand problem. Although it is a very secure program, property owners do not prioritise [building retrofits] very much', he told. 'Initially the question was, can we really get private financing for retrofitting buildings? And the answer is yes. Now the question is, can we get building owners to participate? We do not know. You can create a great program, but without customers it is not doing much. We need to find out the mindset of building owners'.

\section{Revolving loan funds: The Amsterdam Investment Fund and the Billion Dollar Green Challenge}

Revolving loan funds are gaining popularity as a means to support the development or retrofitting of low-carbon buildings or even city areas. Funds are 'revolving' because once paid back to the central fund it is able to issue new loans to other projects (Boyd, 2013; Chou et al., 2014; Indvik, Foley and Orlowski, 2013).

The Amsterdam Investment Fund is a typical example of a revolving loan fund. It was established by the Amsterdam City Council in 2011 to fund projects that contribute to the built environment sustainability goals of the City of Amsterdam, which include a 40 per cent reduction of carbon emissions by 2025, as of 1990 emissions, and a 70 per cent reduction by 2040 (City of Amsterdam, 2011). Within the fund, $€ 70$ million is earmarked to financially support building and city development projects that seek energy reductions or local energy generation. It funds two types of projects: safe investment projects that have a high likelihood of paying back loans supplied, and projects that are more risky and might not be able to repay the loan. The first category compromises 80 per cent of loans issued, and now funds fairly conventional energy upgrades such as the

\footnotetext{
${ }^{7}$ Private owners (small and medium sized firms and individuals) own approximately 50 per cent of commercial property in Melbourne's central business district; the remaining 40 per cent is owned by governments, NGOs, or does not have an ownership classification (City of Melbourne, 2013).
} 
instalment of over 10,000 solar panels on the city's flagship soccer stadium. The other 20 per cent of loans are issued to highly innovative projects, such as citizen-run energy utilities. Loans are supplied at a 4.5 per cent interest rate-which is used to support the costs of managing the Fund as well as to establish a pool of money that cover losses that might occur from the second category of loans. To keep the managerial costs low the Fund only issues funding of $€ 2.5$ million and up. By 2015 the fund had invested some $€ 14$ million, predominantly in the safe investment category. ${ }^{8}$

Another take on revolving loan funds is the Billion Dollar Green Challenge in the United States. It was implemented in 2011 by the Sustainable Endowments Institute, a project within the Rockefeller organisation, and challenges property owners to invest a total of US \$1 billion in selfmanaged revolving loan funds to finance energy efficiency improvements to educational facilities. The Challenge seeks to attract educational organisations (universities and colleges) and environmental non-profits. It does not provide funds itself, but seeks to make the concept and advantages of revolving loan funds better known throughout the United States' education sector. It supports participating organisations with guidelines on how to set up self-managed revolving loan funds, with computer software to track their own performance and to compare it with the performance of other participants, and with case studies from others on how to improve the energy efficiency of educational buildings (Bornstein, 2015). The Challenge does not require its participants to achieve a specified increase in energy efficiency or reduction in carbon emissions. By 2015, some 50 universities and colleges had participated in the Challenge, with US $\$ 110$ million committed to self-managed revolving loan funds.

Again this performance needs to be put in some perspective before it can be evaluated as promising, or less so. The narrative of the Billion Dollar Green Challenge broadly follows that of the two environmental upgrade agreement instruments discussed above. The instrument seems to be of interest particularly to the larger and better known universities in the United States-including Harvard and Princeton-and not the smaller and less prestigious. ${ }^{9}$ To put the performance in another light, whilst the $\$ 110$ million committed represents about 11 per cent of the Challenge's aim, the 50 participating universities represent a mere one per cent of the close to 5,000 universities and colleges in the United States that are targeted by the Challenge. ${ }^{10}$ That said, the Challenge has also resulted in less measurable and quantifiable outcomes: a wealth of documented best practices for designing and managing revolving loan funds is available, free of charge, from the Challenge's websites, as are case studies and white papers on how to carry out building energy upgrades. Such

\footnotetext{
${ }^{8}$ Combined data from www.amsterdam.nl/wonen-leefomgeving/energie/amsterdams/amsterdams and www.akef.nl/investeringen (14 April 2015).

${ }^{9}$ See www.greenbillion.org for the full participant base (29 December 2015).

${ }^{10}$ Data from: www.nces.ed.gov (12 August 2015).
} 
'soft' or 'indirect' outcomes may have a transformative impact on the educational sector, but without being visible in the instrument's performance documentation-this is an issue that holds for all instruments studied.

The performance narrative of the Amsterdam Investment Fund is more complex. The Fund was proposed in 2009 by one of the city's Aldermen as a vehicle for investing income generated from selling bonds that the city owned in a privatised electricity utility, worth $€ 750$ million. 'The underlying idea of the fund was property for property', a fund administrator (int. 67) explained, 'the money from the bonds has to be invested in local sustainability projects, in city development, and in projects that contribute to the local economy and Amsterdam's innovativeness'. The Amsterdam City Council took up this idea and agreed to install a $€ 200$ million revolving loan fund to support building and city development projects that improve Amsterdam's economic competitiveness, urban sustainability, and social aspects (Teulings, 2013). At local level the Fund has become the topic of much debate and critique for not achieving expected results (Boonstra, 2013). A 2013 evaluation of the Fund points out considerable problems (Teulings, 2013). The evaluation summarises a long and grim political battle in the Amsterdam City Council over the Fund. It is particularly critical of the descaling of the City of Amsterdam's financial commitment to the fund-from $€ 750$ million to $€ 200$ million to $€ 70$ million - and the slow release of funds. It also points out that the specific selection criteria for projects led to conflicts in practice: by requiring a market return of (at least) 4.5 per cent on investments the Fund puts truly innovative solutions to sustainable buildings in a difficult position. The nature of an innovative solution is that it cannot, normally, guarantee a positive return. In other words, projects that are awarded funds in the first category (the 'safe investment' category) are not pushing the envelope of what is possible, but applying well-trialled and fairly financially lowrisk solutions-for instance the instalment of solar panels on the city's flagship soccer stadium. The fund is criticised, finally, because of the relatively large size of loans it provides: a loan of $€ 2.5$ million or more is not attractive to small projects, which de facto excludes firms and individuals who seek support for small projects from the Fund. As a result of this critique the Fund has been adjusted and now provides funding starting at $€ 500,000 .^{11}$

\section{Energy efficiency mortgages in the Netherlands and the United States}

Comparable to the environmental upgrade agreements, energy efficiency mortgages seek to take away risks experienced by finance providers, and provide funds to (prospective) homeowners to support the costs of energy efficiency measures for their new or existing homes. These mortgages have a long history in the United States: the United States Federal Housing Administration

\footnotetext{
${ }^{11}$ In 2015, it was rebranded the Amsterdam Energy Fund.
} 
implemented the Energy Efficient Mortgage Program in 1995. It recognises that homeowners can reduce their utility expenses through energy retrofits or upgrades to their houses-making them more able o pay back mortgages - and allows those who seek to do so to top up their approved mortgage. It considers energy savings as additional disposable income that improves a borrower's ability to pay, and thus reduces the risk for finance providers (U.S. Department of Housing and Urban Development, 1995). Homeowners are allowed additional mortgages that are less than the expected savings from energy upgrades of new or existing homes-estimated energy savings must be determined through an acknowledged system or by an acknowledged energy consultant. Maximum mortgage limits are set at five per cent of the property. Mortgages issued under the Energy Efficient Mortgage Program are insured by the Federal Housing Administration, which secures finance providers against loan default. The Program has resulted in a number of spin-off programs. The states of Colorado, Maine and New York, for example, trialled Energy Star Mortgages: by injecting capital into energy efficiency mortgages they aimed to lower the interest rates for borrowers, making it more attractive for them to carry out home energy upgrades. Typically these mortgages are marketed as a win-win opportunity: homeowners can save costs by reducing their energy consumption, which at the same time reduces the carbon emissions of their homes (Kats et al., 2012).

A different take on energy efficiency mortgages is the Additional Credit for Energy Efficient Homes ("Tijdelijke Regeling Hypothecair Krediet") implemented by the Netherlands Ministry of Finance in 2012. It is a temporary lifting of restrictive home mortgage regulations for the period 2012 to 2018, allowing mortgage suppliers to issue higher mortgages to lenders who seek to improve the energy efficiency of their (future) house. In 2012 they were allowed to lend up to six per cent more than the value of the house at the time of transaction (with a maximum of $€ 8,000$ ), in 2013 up to five per cent, and so on until the temporary program is phased out again in 2019. A specific temporary rule allows mortgage suppliers to lend up to $€ 25,000$ more than the value of the house at the time of transaction to lenders who seek to make their (future) house energy neutral (Dutch Ministry of Finance, 2012). This program sits within a larger policy of government backed mortgages.

Yet again, there has been no real impact from these energy efficiency mortgages. For example, the largest and oldest of these, the United States Federal Housing Administration's Energy Efficient Mortgage Program, issued fewer than 6,000 mortgages in the period 2006-2014 (Federal Housing Administration, 2011, 2012, 2013, 2014). To put these numbers in perspective: in its best year thus far, 2011, out of almost 15 million mortgages issued throughout the United States a mere 1,065 were issued under the program -representing less than one in 10,000 mortgages issued that 
year. Reviews of these mortgages highlight a number of problems that explain their low uptake (ACEEE, 2013; Dwars, 2013; Kats et al., 2012). On the demand side there is limited interest in energy efficiency retrofits. Homeowners simply do not demand these mortgages because they are generally not interested in retrofitting their homes. Those who are interested in doing so often already have the funds for retrofits, or consider the paperwork and other related administrative efforts too much hassle for the relatively small (additional) mortgage provided through these programs (Kolstad, 2014). On the supply side, finance providers are also found hesitant about issuing these mortgages. One of their recurring arguments is that technical energy retrofits and upgrades do not guarantee energy savings by consumers, because consumer behaviour also plays an important role. If consumers use more energy because they feel this is accepted because they (now) occupy an energy efficient house-known as the rebound effect (Sunikka-Blank and Galvin, 2012) -their cost-savings lessen, making them less able to pay back the additional mortgage. Such considerations mean that finance providers do not actively market this type of mortgage-which in its turn means that consumers are often not aware of these mortgages (Allen, Barth and Yago, 2012; BuildingBusiness, 2015).

\section{Discussion: How to improve the uptake of novel financing instruments?}

The funding programs studied are sobering: they suggest that even when property developers or owners are provided with novel forms of financing for low-carbon building development or the retrofitting of existing buildings they do not take them up in great numbers. Of course, this finding has to be considered in line with the data presented. This article has discussed six instruments fitting three specific types in Australia, the Netherlands, and the United States. Other (types of) instruments in other countries may yield different results (for more promising instruments, see, for example, Rosenow, Eyre, Burger and Rohde, 2013). That said, similar patterns of marginal performance (in terms of uptake) were identified in five other novel forms of financing that were studied in these countries as part of the larger research project on experimental governance for lowcarbon building and city development and transformation-which cannot be discussed here due to space limitations. ${ }^{12}$

What explains this marginal uptake? A number of design, implementation, and marketing flaws stand out in these instruments. One major issue involves the specific property owners targeted and the way they are attracted to the instruments. This holds specifically for PACE and 1200 Buildings, and to some extent for the Billion Dollar Green Challenge. These instruments target a broad suite of property owners-from very large owners to small ones, as well as owner-users. The

\footnotetext{
${ }^{12}$ For more information on this study and these other five instruments, see note 1.
} 
instruments market themselves, however, as being particularly attractive to large property owners. The narrative of environmental leadership, attracting investors, and improving the corporate image may resonate well with large property owners (including leading universities in the United States) but it appears to be of less interest to the smaller ones. The property sector is a very heterogeneous market. Often this is not well understood by policymakers and practitioners (and academics alike) involved in novel forms of financing and other forms of experimental governance for low-carbon building, and city development and transformation (Van der Heijden, 2014b). To be attractive to a broad suite of property owners these instruments have to acknowledge this heterogeneity and target different segments of the property market. Different segments may require different marketing narratives.

A second and related issue is that specifically smaller (commercial) property owners and owner-users often need relatively small funds for retrofits. Such small funds are, however, relatively expensive for the finance suppliers and administrators of the novel forms of financing. The administrative costs of issuing and collecting a small loan are roughly comparable to those of a large loan, and thus suppliers and administrators prefer to issue large loans. This is true specifically for the Amsterdam Investment Fund and PACE. The administrator of PACE in San Francisco (int. 179) explained: 'With the current PACE structure [which comes with high internal costs] investors only want to buy $\$ 500 \mathrm{k}$ bonds. Yet, there are many $\$ 100 \mathrm{k}$ solar projects that need funding too. A plan would be to set up a fund for those'. Not only would smaller loans allow smaller property owners access to these instruments, it would also improve the equity of a government supported instrument such as the Amsterdam Investment Fund. After all, the local soccer team just around the corner from the city's flagship soccer stadium may equally want to improve the energy efficiency of their property, but because they do not need more than $€ 500,000$ for a retrofit they do not have access to the Fund. One may wonder which of the two organisations is more in need of this support-the multi-million Euro organisation that manages the flagship soccer stadium, or the largely voluntarily run local soccer club.

A third issue is that many property owners are not aware of these novel forms of financing, let alone the benefits of owning and using low-carbon buildings. This is true specifically for the energy efficiency mortgages, but also for the environmental upgrade agreements studied here. The studies cited (ACEEE, 2013; Dwars, 2013; Kats et al., 2012) highlight the fact that mortgage suppliers generally do not inform mortgage seekers about the possibility of an energy efficiency upgrade. Government-initiated information programs in this area are often found not to yield desired results (Hoffman, 2015). Instead of information programs, governments may mandate mortgages suppliers to provide information to mortgage seekers, but that would still require mortgage seekers to make a 
choice in favour of these mortgages or not. The same studies also highlight that building owners are generally not interested in the mortgage because of the disruption involved in having their (future) house retrofitted or the effort required to fill out all the forms necessary to obtain the energy efficiency mortgage. A solution here could be a different approach to offering these mortgages. Learning from insights from behavioural economics one might, for example, think of changing the current voluntary opt in system to a voluntary opt out system (Thaler and Sunstein, 2009). Under such an approach (future) home-owners seeking a mortgage are given the energy efficiency mortgage as a default, but are allowed to reject it if they do not want it. Whilst this approach to offering mortgages by changing the default may be considered somewhat paternalistic, it may help in changing societal norms around building energy efficiency retrofits, particularly in the residential sector, as well as boosting the market for such retrofits.

\section{Conclusion}

This article has studied six innovative forms of financing for low-carbon building development and transformation. It found that they struggled to attract substantial numbers of participants (the caveats of the study were discussed above). This is troublesome because there are often high expectations about eco-financing and other experimental governance instruments for improved urban sustainability from governments, the private sector, and academics around the globe.

To return to the core questions underlying this article: Are these instruments capable of accelerating a transition to low-carbon buildings and cities and how might they achieve this? The research presented suggests that reducing financing barriers that are often argued to stand in the way of property owners (voluntarily) reducing the carbon intensity of their buildings may be necessary, but it is clearly not sufficient. Investment in improved building energy efficiency is a complex topic with many barriers to action. 'Simply' providing funds does not overcome all these barriers (see also Janda, 2014). This raises important questions about the need to scale up these instruments. The general pattern of a lack of interest from property owners, and these instruments lack of fit with their needs, requires a rethinking of the instruments, rather than a blind copy/pasting of them from one context to the next. In the previous section I have suggested three possible changes to these instruments that may improve their uptake. Future researchers may be interested in testing these propositions, or making alternative ones.

The second core question underlying this article asked: What are the values of these instruments, and what are their limits? The value of the novel forms of financing lies in, particularly, the best practices and knowledge created about how to retrofit existing buildings and cities, and to develop new buildings and cities with lower carbon intensities. Most of the instruments studied are 
described on websites that provide a wealth of information about these issues, free of charge and openly accessible to whoever is interested. This highlights, once more, the need to look beyond mere structures built and carbon emissions reduced when assessing the performance of experimental urban governance instruments. That said, the limits of these instruments should not be taken lightly. There appears a structural mismatch between what property owners say they want (access to funding), what it is they do when they are offered what they say they want (not accessing this funding). There also appear some inherently conflicting interests on the side of the finance providers and administrators involved in these instruments (including, but not limited to, guaranteeing a return on investment with trialling novel approaches to reducing carbon emissions at building and city level).

In terms of the broader trend of experimental urban governance, this article contributes to a growing critical literature. Thus far experimental urban governance has been more theorised than studied empirically. This article notes some of the emerging criticisms of experimental urban governance-for example, problems of scaling up experiments, or problems of copy-pasting an experiment from one context to the next. The research also points to an issue that has so far been little discussed: who creates the value of an experiment and how? The administrators of the instruments studied are active in marketing the 'successes' achieved in glossy brochures and on professional looking websites. By looking behind the scenes of the success stories presented by administrators, this research has indicated a consistent pattern of marginal impact when the performance of these instruments is contrasted with the full pool of participants it targets, or the full scale of the problem it seeks to address. Whether this pattern of marginal impact is unique to the set of examples studied here, holds more generally for eco-financing, or even applies to experimental urban governance more broadly is ultimately a question for future empirical research. 
Tables

Table 1 - Brief summary of the characteristics of the six novel forms of financing

\begin{tabular}{|c|c|c|c|c|c|c|}
\hline Characteristics & 1200 Buildings & $\begin{array}{l}\text { Additional Credit for } \\
\text { Energy Efficient } \\
\text { Homes }\end{array}$ & $\begin{array}{l}\text { Amsterdam } \\
\text { Investment Fund }\end{array}$ & $\begin{array}{l}\text { Billion Dollar Green } \\
\text { Challenge }\end{array}$ & $\begin{array}{l}\text { Energy Efficient } \\
\text { Mortgage }\end{array}$ & $\begin{array}{l}\text { PACE (Property } \\
\text { Assessed Clean } \\
\text { Energy) }\end{array}$ \\
\hline Type & $\begin{array}{l}\text { Environmental } \\
\text { upgrade financing }\end{array}$ & $\begin{array}{l}\text { Energy efficiency } \\
\text { mortgage }\end{array}$ & Revolving loan fund & Revolving loan fund & $\begin{array}{l}\text { Energy efficiency } \\
\text { mortgage }\end{array}$ & $\begin{array}{l}\text { Environmental } \\
\text { upgrade financing }\end{array}$ \\
\hline Year established & 2010 & 2012 & 2011 & 2011 & 1995 & 2008 \\
\hline Location & Melbourne, Australia & The Netherlands & $\begin{array}{l}\text { Amsterdam, the } \\
\text { Netherlands }\end{array}$ & United States & United States & $\begin{array}{l}\text { Various cities in the } \\
\text { United States }\end{array}$ \\
\hline Initiator & $\begin{array}{l}\text { City of Melbourne } \\
\text { Government }\end{array}$ & National Government & $\begin{array}{l}\text { City of Amsterdam } \\
\text { Government }\end{array}$ & $\begin{array}{l}\text { Non-profit } \\
\text { organisation }\end{array}$ & Federal Government & $\begin{array}{l}\text { Non-profit } \\
\text { organisation }\end{array}$ \\
\hline Brief description & $\begin{array}{l}\text { Instrument that } \\
\text { bridges the City of } \\
\text { Melbourne } \\
\text { government, finance } \\
\text { providers, and } \\
\text { commercial property } \\
\text { owners. It aims for a } \\
38 \text { per cent reduction } \\
\text { of rule-takers' } \\
\text { building related } \\
\text { energy consumption. }\end{array}$ & $\begin{array}{l}\text { Voluntary mortgages } \\
\text { for (future) home } \\
\text { owners to make } \\
\text { energy efficiency } \\
\text { improvements to } \\
\text { new or existing } \\
\text { residential property. }\end{array}$ & $\begin{array}{l}\text { Revolving loan fund } \\
\text { that financially } \\
\text { supports projects } \\
\text { that add to the City } \\
\text { of Amsterdam's } \\
\text { environmental } \\
\text { sustainability goals. }\end{array}$ & $\begin{array}{l}\text { Instrument that } \\
\text { challenges colleges } \\
\text { and universities to } \\
\text { set up self-managed } \\
\text { revolving loan funds } \\
\text { for building retrofits; } \\
\text { sole focus on existing } \\
\text { commercial property }\end{array}$ & $\begin{array}{l}\text { Voluntary mortgages } \\
\text { for (future) home } \\
\text { owners to make } \\
\text { energy efficiency } \\
\text { improvements to } \\
\text { new or existing } \\
\text { residential property. }\end{array}$ & $\begin{array}{l}\text { Instrument that } \\
\text { allows municipalities } \\
\text { to issue bonds for } \\
\text { commercial building } \\
\text { retrofits. Applied in } \\
30 \text { states in the } \\
\text { United States. }\end{array}$ \\
\hline $\begin{array}{l}\text { Participant rewards } \\
\text { besides funds }\end{array}$ & $\begin{array}{l}\text { Information on } \\
\text { building retrofits; } \\
\text { networking platform. }\end{array}$ & None. & $\begin{array}{l}\text { Information on low- } \\
\text { carbon building } \\
\text { development and } \\
\text { transformation. }\end{array}$ & $\begin{array}{l}\text { Information on } \\
\text { building energy } \\
\text { upgrades. }\end{array}$ & None. & $\begin{array}{l}\text { Information on } \\
\text { building retrofits. }\end{array}$ \\
\hline
\end{tabular}




\section{References}

ACEEE. (2013). Energy Efficient Mortgage. Washington, D.C.: Energy Efficient Mortgage.

Ali, P., \& Yano, K. (2004). Eco-Finance. The Hague: Kluwer.

Aliento, W. (2014, 23 January 2014). Retrofits: how Melbourne can encourage private interests to engage with public ones. Retrieved from http://www.thefifthestate.com.au/property/commercial/retrofits-how-melbourne-canencourage-private-interests-to-engage-with-public-ones/58407

Allen, F., Barth, J., \& Yago, G. (2012). Fixing the Housing Market. Philadelphia: Wharton School Publishing.

Ameli, N., \& Brandt, N. (2015). What Impedes Household Investment in Energy Efficiency and Renewable Energy? Paris: OECD Publishing.

Bai, X., Roberts, B., \& Chen, J. (2010). Urban sustainability experiments in Asia. Environmental Science \& Policy, 13(4), 312-325.

Bals, C., Warner, K., \& Butzengeiger, S. (2006). Insuring the uninsurable: design options for a climate change funding mechanism. CLIMATE POLICY, 6(6), 637-647.

Bird, S., \& Hernandez, D. (2012). Policy options for the splitincentive. Energy Policy, 48, 506-514.

Boonstra, W. (2013, 6 November 2013). Gemeente Amsterdam erkent falen investeringsfonds. Binnenlands Bestuur.

Bornstein, D. (2015, 6 February 2015). Investing in Energy Efficiency Pays Off. New York Times. Retrieved from http://opinionator.blogs.nytimes.com/2015/02/06/investing-in-energyefficiency-pays-off/

Borzel, T. (2012). Experimental governance in the EU. Regulation \& Governance, 6(3), 378-384.

Boyd, E., \& Ghosh, A. (2013). Innovations for enabling climate governance. Environment and Planning C, 31(5), 926-945.

Boyd, S. (2013). Financing and Managing Energy Projects Through Revolving Loan Funds. Sustainability, 6(6), 345-352.

BuildingBusiness. (2015, 6 Amrch 2015). Regeling extra hypotheek moet meer bekendheid krijgen. Retrieved from http://www.buildingbusiness.nl/news/2801/15/Regeling-extra-hypotheekmoet-meer-bekendheid-krijgen/

Bulkeley, H. (2002). Cities and Climate Change. New York: Routledge.

Bulkeley, H., \& Broto, V. (2013). Government by experiment? Transactions of the Institute of British Geographers, 38(3), 361-375.

Castellucci, L., \& Markandya, A. (2012). Environmental Taxes and Fiscal Reform. Houndsmill: Palgrave Macmillan.

Chou, B., Hammer, B., \& Levine, L. (2014). Using State Revolving Funds to Build Climate-Resilient Communities. New York: National Resource Defence Council.

City of Amsterdam. (2011). Structurrvisie Amsterdam. Amsterdam: City of Amsterdam.

City of Melbourne. (2013). 1200 Buildings Melbourne Retrofit Survey 2013. Melbourne: City of Melbourne.

Coiacetto, E., \& Bryant, L. (2014). How Does Access to Development Finance Shape our Cities? Urban Policy and Research, 32(3), 305-321.

da Silva, M. (2011). Melbourne City Council to broker green retrofits. Ethical Investor, 97(June), 1415.

Davis, M. (2011). Behavior and Energy Savings. New York: Environmental Defense Fund.

De Burca, G. (2010). New Governance and Experimentalism. Wisconsin Law Review, 227, 227-238.

Dutch Ministry of Finance. (2012). Tijdelijke regeling hypothecair krediet: FM/2012/1887 M. the Hague: Dutch Ministry of Finance.

Dwars, O. (2013). Haastige spoed is zelden goed! Retrieved from http://www.bouwendnederland.nl/nieuws/33884/column--haastige-spoed-is-zelden-goedook-bij-extra-financiering-energiezuinige-woningen 
Evans, J. (2011). Resilience, ecology and adaptation in the experimental city. Transactions of the Institute of British Geographers, 36(2), 223-237.

Federal Housing Administration. (2011). Annual Management Report: Fiscal year 2011. Washington, D.C.: U.S. Department of Housing and Urban Development.

Federal Housing Administration. (2012). Annual Management Report: Fiscal year 2012. Washington, D.C.: U.S. Department of Housing and Urban Development.

Federal Housing Administration. (2013). Annual Management Report: Fiscal year 2013. Washington, D.C.: U.S. Department of Housing and Urban Development.

Federal Housing Administration. (2014). Annual Management Report: Fiscal year 2014. Washington, D.C.: U.S. Department of Housing and Urban Development.

Hoffman, A. J. (2015). How Culture Shapes the Climate Change Debate. Stanford: Stanford University Press.

Hohn, U., \& Neuer, B. (2006). New urban governance: Institutional change and consequences for urban development. European Planning Studies, 14(3), 291-298.

Indvik, J., Foley, R., \& Orlowski, M. (2013). Green Revolving Funds. Cambridge, MA: Sustainable Endowments Institute.

IPCC. (2014). Climate Change 2014. Cambridge: Cambridge University Press.

James, P. (2015). Urban Sustainability in Theory and Practice. London: Routledge.

Janda, K. (2014). Building communities and social potential. Energy Policy, 67(April 2014), 48-55.

Kats, G., Menkin, A., Dommu, J., \& DeBold, M. (2012). Energy Efficiency Financing. Washington, D.C.: Capital E.

Kirkpatrick, J., \& Bennear, L. (2014). Promoting clean energy investment. Journal of Environmental Economics and Management, 68(2), 357-375.

Kolstad, L. (2014). Designing a Mortgage Process for Energy Efficiency. Washington, D.C.: American Council for an Energy-Efficient Economy.

Matthews, J. (2012). Green growth strategies-Korean initiatives. Futures, 44(8), 761-769.

Matthews, J. (2015). Greening of Capitalism. Stanford: Stanford University Press.

PACE Now. (2015). Annual report 2014. Pleasantville: PACE Now.

Panayotou, T. (1998). Instruments of Change. Abingdon: Earthscan.

Perinotto, T. (2014). Melbourne 1200 Building Programs on HVAC 101. Retrieved from http://www.thefifthestate.com.au/innovation/energy/melbourne-1200-building-programson-hvac-101/62307

Pivo, G. (2010). Owner-Tenant Engagement in Sustainable Property Investing. The Journal of Sustainable Real Estate, 2(1), 183-199.

Rosenow, J., Eyre, N., Burger, V., \& Rohde, C. (2013). Overcoming the Upfront Investment Barrier. Energy \& Environment, 24(1-2), 83-103.

Sabel, C., \& Zeitlin, J. (2011). Experimentalist Governance. In D. Levi-Faur (Ed.), The Oxford Handbook of Governance (pp. 169-185). Oxford: Oxford University Press.

Sanderson, I. (2002). Evaluation, policy learning and evidence-based policy making. Public Administration, 80(1), 1-22.

Sassen, S. (2015). Bringing Cities into the Global Climate Framework. In C. Johnson, N. Toly, \& H. Schroeder (Eds.), The Urban Climate Challenge (pp. 24-36). London: Routledge.

Sichtermann, J. (2011). Slowing the Pace of Recovery. Valparadiso University Law Review, 46, 263309.

Sunikka-Blank, M., \& Galvin, R. (2012). Introducing the prebound effect. Building Research \& Information, 40(3), 260-273.

Swan, W., \& Brown, P. (2013). Retrofitting the Built Environment. Oxford: John Wiley \& Sons.

Teulings, B. (2013). Balanceren tussen maatschappelijk en financieel rendement Amsterdam: BartTeulings Programma-Management en Advies.

Thaler, R., \& Sunstein, C. (2009). Nudge - revised edition. London: Penguin. 
U.S. Department of Housing and Urban Development. (1995). Mortage Letter 95-46. Washington, DC: U. S. Department of Housing and Urban Development

Van der Heijden, J. (2014a). Experimentation in policy design. Policy Sciences, 47(3), 249-266. doi:10.1007/s11077-013-9184-z

Van der Heijden, J. (2014b). Governance for Urban Sustainability and Resilience. Cheltenham: Edward Elgar.

Van der Heijden, J. (2016). The new governance for low-carbon buildings: mapping, exploring, interrogating. Building Research \& Information, online first. doi:10.1080/09613218.2016.1159394

Venugopal, M., Srivastava, A., \& Polycarp, C. (2012). Public Financing Instruments to Leverage Private Capital for Climate-Relevant Investment. Washington, D.C.: World Resources Institute.

Wang, X., Hawkings, C., \& Berman, E. (2014). Financing Sustainability and Stakeholder Engagement. Urban Affairs Review, 50(6), 806-834.

Wang, X., Stern, R., Limaye, D., Mostert, W., \& Zhang, Y. (2013). Unlocking Commercial Financing for Clean Energy in East Asia. Washington, DC: World Bank.

World Bank. (2011). Climate Change and the World Bank Group. Washington, D.C.: The World Bank. 